\title{
Correction to: Security analysis of an audio data encryption scheme based on key chaining and DNA encoding
}

\author{
Imad El Hanouti ${ }^{1}$ (D) Hakim El Fadili $^{1}$
}

Published online: 1 February 2021

(C) Springer Science+Business Media, LLC, part of Springer Nature 2021

\section{Correction to: Multimedia Tools and Applications (2021)}

https://doi.org/10.1007/s11042-020-10153-8

In the line before Eq. 11 in the original publication, an expression contains a mistake. The original article has been corrected.

Publisher's note Springer Nature remains neutral with regard to jurisdictional claims in published maps and institutional affiliations.

The online version of the original article can be found at https://doi.org/10.1007/s11042-020-10153-8

Imad El Hanouti

imad.elhanouti@usmba.ac.ma

1 Computer Science and Interdisciplinary Physics Laboratory (LIPI), SMBA University, Fez, Morocco 